\title{
Rвевавсн Автісів: Assessment of various sources of nutrients on growth, yield and yield components of bottle gourd [Lagenaria siceraria L.]
}

\section{SATISH SINGH BAGHEL, U.S. BOSE, RAJESH SINGH AND S.S. SINGH}

Article Chronicle: Received :

19.07.2017;

Accepted :

03.08.2017

KeY Words:

Bottle gourd,

Vermicompost,

Poultry manure, FYM, Vine length

Author for correspondence :

SATISH SINGH BAGHEL

College of Agriculture

(JNKVV), REWA (M.P.)

INDIA

Email : rewahortic@

gmail.com

See end of the article for authors' affiliations
SUMMARY : A field trial was carried out to the Assessment of various sources of nutrients on growth, yield and yield components of bottle gourd [Lagenaria siceraria L.]. The experimental material for the present investigation was comprised of sixteen treatments with three replications. The results revealed that the plants received 100\% RDF of NPK + FYM @ $10 \mathrm{t} \mathrm{ha}^{-1}+$ Vermicompost @ $5 \mathrm{t} \mathrm{ha}^{-1}+$ Poultry manure @ $2.5 \mathrm{tha}^{-1}$ had a beneficial effect on bottle gourd viz., maximum vine length $(82.96 \mathrm{~cm})$, number of branches plant ${ }^{-1}$ (6.33), minimum days taken for first male (43.39) as well as female flower initiation (49.87) that appeared at earliest node for first male and female flower (17.72 and 19.96, respectively). INM packages on Maximum fruit length $(22.71 \mathrm{~cm})$, fruit girth $(8.68 \mathrm{~cm})$, minimum pedicle length $(7.58$ $\mathrm{cm})$, maximum fruit weight $(568.43 \mathrm{~g})$ and fruit yield ha ${ }^{-1}(463.31 \mathrm{q})$ was found in same treatment.

How to cite this article : Baghel, Satish Singh, Bose, U.S., Singh, Rajesh and Singh, S.S. (2017). Assessment of various sources of nutrients on growth, yield and yield components of bottle gourd [Lagenaria siceraria L.]. Agric. Update, 12(TECHSEAR-7) : 1940-1945; DOI: 10.15740/HAS/AU/12.TECHSEAR(7)2017/1940-1945. 